\title{
Sustainability Reporting of Islamic Commercial Bank: Comparative study in Indonesia and Malaysia
}

\author{
Falikhatun ${ }^{1}$, Afifah Oki Nilasakti ${ }^{2}$, Milananda Ainun Niswah ${ }^{3}$ \\ Universitas Sebelas Maret, Indonesia ${ }^{1,2,3}$ \\ \{falie.feuns17@gmail.com¹, afifahoki@gmail.com²,milanandaa22@gmail.com\}
}

\begin{abstract}
Sustainability reporting is important issue which has implications for stakeholder on supporting business entity. Therefore, this study examines the influence of sharia supervisory boards, investment account holders and financial slack on sustainability reporting of Islamic commercial banks in Indonesia and Malaysia for the year 2015 to 2018 also determine the difference on their sustainability reporting. Data analysis uses panel data regression and different tests through eviews 10 . The results reveale that IAH and financial slack have effect on sustainability reporting of Islamic commercial bank in Indonesia, while SSB has no effect. Meanwhile, SSB has effect on sustainability reporting of Islamic commercial bank in Malaysia then IAH and financial slack have no effect. In addition, the results of the independent-t test indicate that there is insignificant differences among sustainability reporting of Islamic banks in Indonesia and Malaysia.
\end{abstract}

Keywords: Financial slack, investment account holder, sharia supervisory board, sustainability reporting

\section{Introduction}

Islamic banking is a large sector in the Islamic finance industry proved from its contribution of $71 \%$ or 1.72 billion USD on the Islamic financial industry assets (prnewswire.com). According to Bandar Hajjar, the president of Islamic Development Bank (as reported by ft.com), in the globalization era, the community which is dominated by the young people demands that values and objectives can be inculcated and applied in the business and financial sector. Since the financial crisis, various questions arose regarding the failure of the financial system at the time which had an impact on society, the environment, social aspect and governance. For Islamic people, the encouragement for developing a new product is not something new because essentially Islamic finance attaches great importance to improving the quality of life. From Islamic business approach, Islamic banks have a responsibility to Allah and the community, which is applied to its business model principle by implementing social ethics and responsibility [1]. Islam recognizes the importance of environmental protection, prohibits recognition non-proprietary status, and business investments that can harm society. Therefore, global financial experts have started to find a sustainable monetary and financial system under Islamic perspective which they consider can become an alternative model for the current modern financial system [2]. As a result, in the 
last few years, many financial institutions have started to implement CSR practice in their operational and organizational strategy. The banking industry has a central role in the community because of its high intensity of social interaction, which makes people expect that the business will be socially responsible [3]. This is in line with the SDGs which encouraged its member countries to start paying attention to the non-financial aspects such as social, economy, and environment besides maximizing their profits.

Sustainability reporting became one of the manifestations of the Sustainable Development Goals (SDGs) programs by the United Nations. Global Reporting Initiative defines sustainability reporting as a media for an organization to measure, understand, and communicate the performance of their governance, economy, social, and environment. GRI adds that in its implementation, sustainability reporting is similar to the triple bottom line reporting, CSR reporting and other non-financial reporting. Globally, organizations are demands to not only claim sustainability but also real and credible action on the level of sustainability by following the appropriate guidelines regarding sustainability reporting [4]. The idea is to make the organization not only have responsibilities that work around the single bottom line (financial condition of the organization) but encourage organizations to work on the triple bottom line (social, environmental and profit). the CSR practice aims to provide social justice for the community [5]. Indirectly, this strategy can be employed by an organization to build stakeholder's trust through transparency as the core trust-building which in turn will support a sustainable business.

The principle of transparency applied by Islamic banks does not reflect the CSR principle, but also as a form of its responsibility to the community and to seek blessing from Allah SWT [6]. CSR disclosure depends on several factors such as the information gathered, state policy, and the Muslim community. This is why, Islamic Banks do not need disclosure policy that includes the information on resources, products, community, and environment. To implement the disclosure policy, the catalyst role of Islamic bank corporate governance in driving CSR disclosure. Further, the organizational involvement in realizing the social responsibility and its disclosure requires larger resources [7]. In addition to corporate governance, slack resources become another addition that might act as a catalyst in creating synergy by utilizing resources for sustainable activities such as CSR [8]. The survey from McKinsey (2010) showed that $76 \%$ of executives believe that CSR can positively affect long-term shareholder value and $55 \%$ agree that CSR can build a strong organizational reputation. The implementation of CSR activities encourages better performance and followed by its disclosure will improve organizational reputation. The benefits can be felt by the environment and society, and for the organization, in the long run, because investors as stakeholders are encouraged to invest more. Organizational slack is classified into two types, unabsorbed slack and absorbed slack. Unabsorbed slack is more flexible, thus it can be used anytime, for example, financial slack [9]. Absorbed slack is the excess of resources that have been specifically allocated so that they are permanent [10].

Global Reporting Initiative is an independent international standard organization that aims to assist the business entity, government, and organization to understand and communicate the impact of their operation activities on the pressing issues such as climate change, human rights, and corruption. GRI becomes the initiator of sustainability reporting or CSR reporting guidelines for an organization by offering reporting and disclosure standard [11], [12]. This standard can be specifically categorized into the conventional aspect such as employees, social, environment, human rights, and other legal problems (GRI, 2013). Islamic banks need a standard in implementing their social responsibility and perform sharia-based reporting. However, several aspects of GRI standard have not included Islamic banks problems such as 
free from riba (interest), speculation, and obedience on other sharia principles such as zakat, waqaf, qardh hasan and sadaqah as well as the role of sharia supervisory board [13]. This drawback encourages the development of a special standard for Islamic banks that based on sharia values determined by the Accounting and Auditing Organization for Islamic Financial Institution (AAOIFI) in line with al-Qur'an and hadits.

Previous studies on the effect of corporate governance on sustainability reporting have been conducted in Islamic banks. [14] examine the CSR reporting affected by several variables such as the size of the Muslim population, Islamic governance score, firm size, and investment account holder. The results show that the Muslim population, Islamic governance, and the IAH have a positive and significant effect on CSR reporting. Other studies conducted by [15]-[19] show that corporate governance has a positive effect on Islamic social reporting. However, a different result is presented by a study conducted by [20] that corporate governance represented by the sharia supervisory board does not affect corporate social reporting. Departing from the diverse results from previous studies, this study aims to reexamine the effect of sharia governance and sustainability reporting in Islamic banks. Organizational slack may become a factor that affects the extent of sustainability reporting; thus, financial slack is added to the research model. The previous study conducted by [21] and [7] shows a positive slack on CSR reporting on the Islamic bank samples. Based on this description, this study will examine the effect of sharia supervisory board, investment account holder and financial slack on sustainability reporting.

\section{Literature Review and Hypothesis Development}

\subsection{Islamic Stakeholder Theory}

Stakeholder theory is in line with an Islamic perspective, a stakeholder in Islam is the party who is at risk from firm's operation, thus stakeholders are not limited to them with an explicit contract but also those who implicitly related to the firm operation [22].The implicit contract is the core of Islamic perspective which is when human is appointed as caliph in earth they will have an implicit contract of responsibility to their God for all activities they have done [23]. The stakeholder theory in Islamic perspective means that firm responsibility does not stop at the horizontal dimension between human and the society but there is also a vertical dimension in which firm's operation are accountable to Allah SWT. There are obligations and responsibility borne by human which they must achieve and the failure to achieve the obligations and responsibility is a treason that has a consequence in life and afterlife. When the society move together, they will be able to minimize conflicts and reach unity. The community will no longer compete for resources but work together as Allah commanded in Q.S ash-Shaff (61): 4. The stakeholder theory in Islamic perspective is the basis for firms in performing sustainability reporting. Islamic stakeholder theory is in line with the stakeholder concept according to [24] on the groups or individual that can affect or be affected by the achievement of company goals. The stakeholder theory states that a firm needs to show its responsibility through accountability to its stakeholders [24].

\subsection{Sharia Supervisory Board}

Islamic bank has different characteristics from a conventional bank, one of which lies in its governance aspect that requires a Sharia Supervisory Board (SSB) [25]. SSB is independent 
and has to supervise, direct, and ensure that the Islamic bank operates under the sharia principles [26]. Besides that, SSB also has to assess information and report regarding the bank's operation, finance, and policy; this authority is similar to those of auditor's [27]. Therefore, SSB might improve supervision and provision of sustainable reporting [2].

\subsection{Investment Account Holder}

The investment account holder is funds deposited by the third party that can be used by Islamic banks. An investment account is a receipt of investment funds from mudharabah muthlaqah, mudharabah muqayyadah, musyarakah, and other similar accounts regulated in FAS (Financial Accounting Standard) no. 27. The investment account holder is reported as an independent category in the statement of financial position.

\subsection{Financial Slack}

Burgeouis (1981) defines slack as potential resources that can be used by an organization to adjust to the internal and external pressure regarding a certain policy. Slack can assist an organization in increasing their long-term profit by performing future competitive innovation [28]. An organization has excess resources such as workforce, inventory, and raw material. However, a slack that has the largest probability to be maximized is the financial slack[29]. Financial slack might present in the form of assets level that is available for an organization such as cash and cash equivalent [30] that are considered as current assets, thus, is flexible to be placed or channeled by management in various uses or purposes [31]. In previous studies, financial slack can be measured from cash reserves and working capital [32]. Cash reserves are represented by cash and cash equivalent in an organization [30], while working capital covers the aspects of level relative current resources of firm's activities [33]. In other words, working capital is measured using net resources of operational assets on the level of activities [34].

\subsection{Hypothesis Development}

Sharia supervisory board has a role in supervising the application of sharia principles. In line with the Islamic stakeholder theory that in their operational activities, an organization is encouraged to be responsible for their stakeholder mainly to Allah SWT and the fellow human, social, and environment. SSB becomes an agent that can encourage the implementation of social responsibility and reporting according to the sharia principles. Previous studies conducted by [2], [21], [35]; and [25] show that sharia supervisory board has a positive effect on corporate social reporting. Thus, the large size of the sharia supervisory board will indicate better supervision on Islamic bank policy, which in turn will expand the sustainability reporting. Therefore, the proposed hypothesis in this study is: $\mathrm{H}_{1}$ : Sharia supervisory board has a positive effect on sustainability reporting.

According to the Islamic Stakeholder theory, the investment account holder is a special category of investors because this account holder is not represented in decision making through the committee, but the account holder or regular customers will keep a supervision on the Islamic commercial banks to invest their funds. Islamic commercial banks will provide more disclosure to attract customers to invest in their products. According to [19], the customer determined the level of sharia principles compliance which affects the sustainability reporting. In investing their funds, customers are not investors because they are attracted to the 
products and services provided by the Islamic commercial banks, but the customer also does not have formal right even if they still maintain supervision on the management.

Customers have a relative effect that will determine how far bank activities will follow the Islamic principles and its effect on the level of disclosure provided by Islamic commercial banks. This shows that a high investment account holder encourages Islamic commercial banks to disclose more through sustainability reporting. Based on this description, the proposed hypothesis is as follows: $\mathrm{H}_{2}$ : Investment account holder has a positive effect on sustainability reporting.

Islamic stakeholder theory supports the development of a good relationship with stakeholders; Allah SWT, fellow human beings and their social and environmental aspects. According to several supporters of stakeholder theory, the social performance of an organization can encourage a good financial performance. Another study argues that if a firm has a good financial performance, thus they will have more resources to be invested in social projects. This is corroborated by an opinion from previous researchers that the improvement in social performance will be triggered by the allocation of slack resources for social activities, which means that financial performance measured using financial slack with a high percentage will be able to encourage better social performance and expand reporting [36], [37] Previous studies conducted by [21], [38] and [7] state that slack measured using financial slack has a positive effect on corporate social reporting. Therefore, the higher the financial slack, the higher the opportunity for a firm to determine policy, one of which is sustainability reporting, thus, proposing the following hypothesis $\mathrm{H}_{3}$ : Financial slack has a positive effect on sustainability reporting.

Southeast Asia is one of the areas that developed into the center of development for Islamic banking and financial industry in the world. Indonesia and Malaysia become the driving force for the development of the Islamic finance industry in the Southeast Asia region. The regulations of the Islamic banking and financial systems in Indonesia and Malaysia have their respective variations. One of the differences is on sustainability reporting. According to Global Reporting Initiative (2018), sustainability reporting is a report published by a firm on the economic, social, and environmental impact of the firm's operations. The policy difference on sustainability reporting in Indonesia and Malaysia is, for example, in Malaysia sustainability reporting regulated by Bursa Malaysia Securities Berhad states that sustainability reporting in Malaysia is mandatory for all firms since 2016. As in Indonesia, sustainability reporting in regulated in Financial Services Authority Regulation Number 51 /POJK.03/2017, article 10 mentions that sustainability reporting is mandatory for financial services institution, issuers, and public companies but sustainability reporting separate from the annual report is voluntary.

Sustainability reporting is a report that provides financial and non-financial information such as firm's performance in environmental, social, and governance fields. There is a difference in the governance system in Indonesia and Malaysia sustainability reporting in term of Sharia Supervisory Board. Sharia Supervisory Board is sharia experts appointed by the General Meeting of Shareholders which has the task of providing advice and suggestions to the board of directors as well as supervising the company's activities to comply with sharia principles. The SSB difference between Indonesia and Malaysia is in the number of SSB members. In Malaysia, SSB should at least consists of three sharia experts selected through General Meeting of Shareholders and do not hold an additional position as a consultant in all Islamic Conventional Banks and/or sharia unit. In Indonesia, based on PBI No. 11/3/PBI/2009 SSB members should not less than 2 persons or a maximum of $50 \%$ of total members of the Board of Directors. Based on the differences in Indonesia and Malaysia, this study proposed 
that there are differences in sustainability reporting between the country. $\mathrm{H}_{4}$ : There are differences in sustainability reporting in Indonesia and Malaysia.

\section{Research Method}

The object of this study is Islamic Conventional Banks in Indonesia and Malaysia. The data analyzed in this study are secondary data from the annual report and sustainability report from Islamic Conventional Banks from 2015 to 2018 and listed in the Financial Services Authority and Bank Negara Malaysia. The samples are selected using a purposive sampling method. The total selected samples are 56 observations in Indonesia and 28 observations in Malaysia. Operational Definition of Variables are follows:

\section{a) Sustainability reporting}

The standard used to assess the component of sustainability reporting indicator is the standard from AAOIFI no 7 of 2010 and from [39]. The Islamic Conventional Bank is given score 1 when they disclose a disclosure item from AAOIFI and given 0 when they do not disclose the item. The score from all items are added and divided by the total number of disclosures. The sustainability reporting index is computed through the following formula:

sustamablity Reporting $=\frac{s \text { disclosed items }}{\text { total disclosure items }}$

\section{b) Shariah Supervisory Board}

The sharia supervisory board is measured based on the previous study conducted by [21] which utilized total SSB members in sharia bank.

$\mathrm{SSB}=\sum$ Sharia Supervisory Board

\section{c) Investment Account Holder}

Investment Account Holder measurement is based on the study conducted by [19] by comparing the total temporary sharia funds to the total assets to assess the level of Investment Account Holder in a firm. The formula to compute the level of Investment Account Holder is as follows:

$$
\text { LAH }=\frac{\text { Total Investment Account Holder }}{\text { Total Asset }}
$$

\section{d) Financial Slack}

The slack resources are measured using the natural logarithm of cash and cash equivalents based on the study conducted by [38] and [7].

Financial Slack $=\ln$ (cash and cash equivalent 


\section{Result and Discussion}

\subsection{Descriptive Statistics}

The descriptive statistics from Indonesia and Malaysia are presented in table 1a and $1 \mathrm{~b}$. the classical assumption test on the data collected from both countries shows that the data has a normal distribution after excluding outlier using studentized residuals.

\begin{tabular}{cccccc}
\multicolumn{6}{c}{ Table 1. Descriptive Statistics Indonesia } \\
\hline & $\mathbf{N}$ & Minimum & Maximum & Mean & Std. Deviation \\
\hline SR & 48 & 0.41 & 0.9 & 0.639 & 0.124 \\
SSB & 48 & 2 & 3 & 2.270 & 0.449 \\
IAH & 48 & 0.224 & 0.892 & 0.685 & 0.128 \\
FSL & 48 & 20.628 & 28.107 & 24.879 & 2.127 \\
Valid N & 48 & & & & \\
\hline
\end{tabular}

Table 1a presents the descriptive statistics from Indonesian samples with a total of 48 observations. The results show the mean, minimum, and maximum score with low range except for FSL. FSL has a minimum score of 20.628 and a maximum score of 28.107 and a mean score of 24.879 which shows large range compared to other variables in this study. This is strengthened with the standard deviations of 2.127 .

Table 2. Descriptive Statistics Malaysia

\begin{tabular}{cccccc}
\hline & N & Minimum & Maximum & Mean & Std. Deviation \\
\hline SR & 27 & 0.49 & 0.81 & 0.665 & 0.093 \\
SSB & 27 & 5 & 9 & 5.777 & 1.012 \\
IAH & 27 & 0.001 & 0.080 & 0.014 & 0.022 \\
FSL & 27 & 23.049 & 31.4753 & 29.254 & 1.883 \\
Valid N & 27 & & & & \\
\hline
\end{tabular}

Table $1 \mathrm{~b}$ shows the distribution of data from SSB and FSL variable which is not evenly distributed with standard deviations of 1.012 and 1.883. This is also supported by a large range of the maximum and minimum score. In total 27 observations passed the classical assumption test.

\subsection{Hyppothesis Testing}

Table 3. The t-test Result on SSB in Indonesia

\begin{tabular}{ccc}
\hline Variable & B & Std. Error \\
\hline C & $-0.383^{* *}$ & 0.151 \\
SSB & -0.023 & 0.031 \\
IAH & $0.290^{* *}$ & 0.107 \\
FSL & $0.033^{* * *}$ & 0.006 \\
Obs & & \\
R-squared & & 0.576 \\
F & & $23.50^{* * *}$ \\
\hline
\end{tabular}

All independent variables, sharia supervisory board, investment account holder and financial slack simultaneously affect sustainability reporting in Indonesia. This finding is summarized in table $3 \mathrm{a}$ with an F score of 23.50 and a significance level of 0.000 which is 
lower than 0.05 . The $57.6 \%$ of the variance in sustainability reporting in Indonesia are explained by SSB, IAH and financial slack with adjusted $\mathrm{R}^{2}$ score of 0.576 , and the rest $41.4 \%$ is explained by other variables outside the model.

Table 2a shows the result of t-test or partial effect of SSB, IAH, and financial slack on sustainability reporting in Indonesia. This result shows that sharia supervisory board does not affect sustainability reporting, thus this finding does not support the hypothesis that sharia supervisory board has a positive effect on sustainability reporting which contradicts previous studies conducted by [2], [21], [35] and [25]. However, this finding supports the study conducted by [16] which is possible because SSB only carries out their responsibility to ensure the transactions and operations of Islamic banks follows sharia regulation [16]. Another factor that supports this finding is the size of SSB of Islamic Commercial Banks in Indonesia is below AAOIFI standard which is three SSB members at a minimum. The below-average measures lead to the lack of supervision from SSB on sustainability reporting.

The probability score from the t-test analysis for the effect of IAH on sustainability reporting at a 5\% significance level with the coefficient value of 0.290 which indicates positive direction. This is in line with the Islamic Stakeholder theory which states that investment account holder owner is a special category of investors because the holder is not represented in the decision making through the board but this account holder will continue performing supervision on Islamic Conventional Bank to invest their funds. This finding supports the study conducted by [19] which states that high third party funds will encourage Islamic Conventional Banks to implement sustainability reporting aimed to attract customers to invest their funds through bank's products and therefore allow them to perform supervision on manager's performance through sustainability reporting.

Financial slack shows a positive and significant effect on sustainability reporting, thus, a high the financial slack can encourage Islamic banks to expand their sustainability reporting. The finding of this study support previous studies conducted by [7], [21], [38]. This result indicates that the level of financial slack owned by a bank can encourage social responsibility actions from the bank and therefore, expanding the sustainability reporting disclosed to stakeholders.

\begin{tabular}{ccc}
\multicolumn{3}{c}{ Table 4. a T-test on SSB in Malaysia } \\
\hline Variable & B & Std. Error \\
\hline C & 0.174 & 0.245 \\
SSB & $0.032^{*}$ & 0.016 \\
IAH & 0.091 & 0.008 \\
FSL & 0.008 & 0.008 \\
Obs & 27 & \\
R-squared & & 0.499 \\
F & & $6.79^{* * *}$ \\
\hline
\end{tabular}

The F-score generated from the analysis is 6.79 with a significance level of 0.000 which is lower than 0.005 . This means that simultaneously, the independent variable of sharia supervisory board, investment account holder, financial slack affect sustainability reporting in Malaysia. Additionally, SSB, IAH and financial slack also explain $49.9 \%$ of the variance in sustainability reporting in Malaysia represented by the adj $\mathrm{R}^{2}$ score of 0.499 . This means another $50.1 \%$ of the variance in the dependent variable is affected by other variables outside the model. Referring to table $2 \mathrm{~b}$, sharia supervisory board shows a positive and significant effect on sustainability reporting. This is indicated by the score of the p-value that is lower than $5 \%$ and a beta coefficient score that shows a positive direction. This indicates that the 
larger the number of SSB members, the wider is the sustainability reporting. This finding supports the study conducted by [2], [21], [25], [35]. This is supported by the minimum number of SSB members in Malaysia follows the AAOIFI policy, which is three members of SSB. This can be interpreted that the number of sharia supervisory board members can encourage accountability manifested in sustainability reporting to stakeholder.

The result of regression analysis shows a non-significant $\mathrm{p}$-value score for the investment account holder (IAH) at $1 \%$ to $5 \%$ significance level, investment account holder does not influence sustainability reporting. The hypothesis which states that investment account holder has a positive effect on sustainability reporting is, therefore, not supported. This result is inconsistent with the study conducted by [19] which find that a high third party deposit will encourage Islamic banks to disclose sustainability reporting to attract customer investment to their products. However, this finding is consistent with the study conducted by [2] which finds that investment account holder does not affect sustainability reporting because the customer does not invest in Islamic commercial banks because of its social and environmental disclosure but focusing solely on its financial performance. Therefore, the number of customer investment funds does not affect sustainability reporting.

The result of t-test analysis shows that financial slack in Malaysia does not affect sustainability reporting. This is shown in the score of p-value higher than the significance level of 5\%. This finding does not support the previous study conducted by [21], [38] and [7] but support the study conducted by [40]. This might be caused by the demand for a bank to maintain high liquidity so that financial slack measured using cash equivalent cannot be used by an Islamic bank to allocate their slack on social activities [40]. Therefore, banks do not focus on CSR activities and its reporting but pay more attention to maintaining their liquidity.

\subsection{Independent t-test}

Before conducting mean difference analysis on Sustainability Reporting in Indonesia and Malaysia, the data were tested for normality and homogeneity using the Shapiro-Wilk test and the Fisher $\mathrm{F}$ test. The result of the tests indicates that the data is normally distributed and homogenous with the significance level of the result higher than 0.05 . After fulfilling the assumptions, the mean difference test is conducted through One Way ANOVA with independent t-test. However, in the case of the data do not fulfill the classical assumption, the test will be performed through Eta test which does not require the data to be homogenous and normally distributed.

Table 5. The Result of Normality Test on SR in Indonesia and Malaysia

\begin{tabular}{cccccc}
\hline Variable & Obs & W & $\mathbf{V}$ & $\mathbf{z}$ & Prob $>\mathbf{z}$ \\
\hline SR IND & 49 & 0.98400 & 0.741 & -0.639 & 0.73859 \\
SR MAY & 28 & 0.95304 & 1.418 & 0.719 & 0.23602 \\
\hline
\end{tabular}

Referring to table 3, the result of the Shapiro-Wilk test on Sustainability reporting in Indonesia and Malaysia shows the score of Sig. 0.73 and 0.23 , which is higher than 0.05 and showed that the data is normally distributed.

Tabel 6. The Result of Homogeneity Test on SR in Indonesia and Malaysia

\begin{tabular}{ccccccc}
\hline Variable & Obs & Mean & Std. Err & Std. Dev & \multicolumn{2}{c}{ 95\% Coef Interval } \\
\hline SR IND & 49 & .6446939 & .0183714 & .1285999 & .6077557 & .6816321 \\
SR MAY & 28 & .6596429 & .0182754 & .0967043 & .6221448 & .6971409 \\
Combined & 77 & .6501299 & .0133969 & .1175573 & .6234476 & .6768121 \\
\hline
\end{tabular}




\begin{tabular}{|c|c|c|c|c|}
\hline Variable & Obs & Mean & Std. Err & 95\% Coef Interval \\
\hline & & & & degrees of freedom $=75$ \\
\hline & & & & $\mathrm{t}=-0.5342$ \\
\hline & & & & $\operatorname{Pr}(|\mathrm{T}|>|\mathrm{t}|)=0.5948$ \\
\hline
\end{tabular}

Fisher $\mathrm{F}$ test is an analysis used to examine the homogeneity of data. Referring to table 4, the result of Fisher $\mathrm{F}$ test on sustainability reporting in Indonesia and Malaysia shows the score of Sig. 0.1141, which indicates that the data is homogenous because Sig. score is higher than 0.05 . The result of normality and homogeneity tests showed that the data has fulfilled the assumption of homogeneity and normal distribution, therefore, the data can be analyzed using One Way ANOVA through independent t-test. We can conclude that there is significant difference between sustainability reporting in Indonesia and Malaysia when the result of the test shows a score lower than 0.05 .

Tabel 7. The Result of Mean Difference Test on Islamic commercial bank's SR in Indonesia and Malaysia

\begin{tabular}{lllllll}
\hline Variable & Obs & Mean & Std. Err & Std. Dev & 95\% Coef Interval \\
\hline SR IND & 49 & 0.644693 & 0.018371 & 0.128599 & 0.607755 & 0.681632 \\
SR MAY & 28 & 0.6596429 & 0.0182754 & 0.0967043 & 0.6221448 & 0.6971409 \\
combined & 77 & 0.650129 & 0.013396 & 0.117557 & 0.623447 & 0.676812 \\
\hline \multicolumn{1}{c}{} \\
\hline
\end{tabular}

Referring to table 5 which shows the result of One-Way ANOVA with independent t-test analysis (Asymp. Sig. 0.5948), we can conclude that $\mathrm{H}_{4}$ is not supported because of the Asymp. Sig. score is higher than 0.05 . This means that there is no significant difference between Sustainability reporting in Indonesia and Malaysia because the only difference found between the two countries are separate sustainability reporting and the number of SSB members.

\section{Conclusion}

This study aims to examine the effect of sharia supervisory board, investment account holder and financial slack on sustainability reporting of Islamic Conventional Banks in Indonesia and Malaysia. The analysis results show that in Indonesia, SSB does not influence sustainability reporting, while IAH and financial slack has a positive influence on sustainability reporting. In Malaysia, SSB has a positive influence on sustainability reporting while IAH and financial slack has no significant influence on sustainability reporting. An independent t-test is performed to determine a significant difference between sustainability reporting Islamic Conventional Banks in Indonesia and Malaysia. The result indicates that there is no significant difference in sustainability reporting of Islamic Conventional Banks in both countries. The limitation of this study is that the finding of the current study cannot be applied as a guideline for countries aside from Indonesia and Malaysia due to the probability of differences in banking conditions. Additionally, the observation period of this study is relatively short which might not be able to provide a detailed description of the condition of Islamic Conventional Banks in Indonesia and Malaysia. 


\section{References}

[1] R. M. Haniffa and T. E. Cooke, "Culture, corporate governance and disclosure in Malaysian corporations," Abacus, vol. 38, no. 3, pp. 317-50, 2002.

[2] S. Farook and L. Roman, "Banking on Islam? Determinants of corporate social responsibility disclosure," Islam. Econ. Financ., vol. 2, no. 17, pp. 355-388, 2007.

[3] M. Agus et al., "Enforcement Rules of the University Act," Int. J. Bus. Soc. Sc, no. 4, pp. 1-21, 2012.

[4] "Why Sustianbility is important of business," In.Corp. [Online]. Available: https://www.incorp.asia/learn/why-sustainability-reporting-is-important-for-businessesin-singapore.

[5] R. Gray, D. Owen, and K. . Maunders, Corporate Social Reporting: Accounting and Accountability. Prentice Hall, 1987.

[6] A. Hassan and S. Syafri Harahap, "Exploring corporate social responsibility disclosure: the case of Islamic banks," Int. J. Islam. Middle East. Financ. Manag., vol. 3, no. 3, pp. 203-227, 2010.

[7] E. Xu, H. Yang, J. M. Quan, and T. Lu, "Organizational slack and corporate social performance : Empirical evidence from China's public firms," Asia Pacific J. Manag., vol. 32, pp. 181-198, 2015.

[8] N. . Foss and J. . Christensen, "A market-process approach to corporate coherence," Manag. Decis. Econ., vol. 22, no. 4/5, pp. 213-26, 2001.

[9] S. W. Bradley, D. A. Shepherd, and J. Wiklund, "The importance of slack for new organizations facing 'tough' environments," J. Manag. Stud., vol. 48, no. 5, pp. 10711-97, 2011.

[10] G. B. Voss, D. Sirdeshmukh, and Z. G. Voss, "The Effects of Slack Resources and Environmental Threat on Product Exploration and Exploitation," Acad. Manag. J., vol. 51, no. 1, pp. 147-164, 2008.

[11] S. Abeydeera, H. Tregidga, and K. Kearins, "Sustainability reporting-more global than local?," Meditari Account. Res., vol. 24, no. 4, pp. 478-5-4, 2016.

[12] T. Khan and R. Gray, "Accounting,identity,autopoiesis+sustainability:Acomment, development and expansion on Lawrence, Botes, Collinsand Roper (2013)," Meditari Account. Res., vol. 24, no. 1, pp. 36-55, 2016.

[13] Z. U. Rehman et al., "Do corporate social responsibility disclosures improve financial performance? A perspective of the Islamic banking industry in Pakistan," Sustain., vol. 12, no. 8, 2020.

[14] Farook, Sayd, M. Kabir Hassan, and R. Lanis, "Determinants of corporate social responsibility disclosure: the case of Islamic banks," J. Islam. Account. Bus. Res., vol. 2, no. 2, pp. 114-141, 2011.

[15] W. Amalina Wan Abdullah, M. Percy, and J. Stewart, "Shari'ah disclosures in Malaysian and Indonesian Islamic banks:The Shari'ah governance system," J. Islam. Account. Bus. Res., vol. 4, no. 2, pp. 100-131, 2013.

[16] F. Hashim, N. D. Mahadi, and A. Amran, "Corporate Governance and Sustainability Practices in Islamic Financial Institutions: The Role of Country of Origin," Procedia Econ. Financ., vol. 31, no. 15, pp. 36-43, 2015.

[17] A. S. Musibah, W. Sulaiman, B. Wan, and Y. Alfattani, "The Mediating Effect of Financial Performance on the Relationship between Shariah Supervisory Board Effectiveness, Intellectual Capital and Corporate Social Responsibility, of Islamic Banks in Gulf Cooperation Council Countries," Asian Soc. Sci., vol. 10, no. 17, pp. 
139-164, 2017.

[18] T. Azid and A. A. Alnodel, "Determinants of Shari'ah governance disclosure in financial institutions: Evidence from Saudi Arabia," Int. J. Ethics Syst., vol. 35, no. 2, pp. 207-226, 2019.

[19] R. Grassa, R. Chakroun, and K. Hussainey, "Corporate governance and Islamic banks' products and services disclosure," Account. Res. J., vol. 31, no. 1, pp. 75-89, 2018.

[20] Z. A. Aribi and S. S. Gao, "Narrative disclosure of corporate social responsibility in Islamic financial institutions," Manag. Audit. Journal, vol. 27, pp. 199-222, 2011.

[21] C. Mallin, H. Farag, and K. Ow-yong, "Journal of Economic Behavior \& Organization Corporate social responsibility and financial performance in Islamic banks," J. Econ. Behav. Organ., vol. 103, no. 3, pp. S21-S38, 2014.

[22] M. Iqbal and P. Molyneux, "Thirty Years of Islamic Banking: History, Performance and Prospects," J. King Abdul Aziz Islam. Econ., vol. 19, no. 1, pp. 37-39, 2006.

[23] Z. Iqbal and A. Mirakhor, "Financial Inclusion : Islamic Finance Perspective," J. Islam. Bus. Manag., vol. 2, no. 1, pp. 35-64, 2012.

[24] R. E. Freeman, Strategic Management: A Stakeholder Approach. Boston Pitman, 1984.

[25] A. A. n Rahma and A. A. Bukair, "The Effect of the Board of Directors' Characteristics on Corporate Social Responsibility Disclosure by Islamic Banks," J. Manag. Res., vol. 7, no. 2, p. 506, 2015.

[26] M. B. Accounting and Auditing Organization for Islamic Financial Institutions (AAOIFI), Accounting, Auditing and Governance Standards (for Islamic Financial Institutions). 2005.

[27] A. A. . Karim, "Accounting and Auditing Standards for Islamic Financial Institutions," in Proceedings of the Second Harvard University Forum on Islamic Finance: Islamic Finance into the 21 Century, 2001, pp. 239-241.

[28] M. . Sharfman, G. Wolf, R. . Chase, and D. . Tansik, "Antecedents of organizational slack," Acad. Manag. Rev., vol. 13, no. 4, pp. 601-614, 1988.

[29] M. . Austin, J. . Pausas, and A. . Nicholls, Patternsof tree species richness in relation to environment in south-eastern New South Wales. Aust: J. Ecol, 1996.

[30] M. S. Kraatz and E. J. Zajac, "How Organizational Resources Affect Strategic Change and Performance in Turbulent Environments: Theory and Evidence.," Organ. Sci., vol. 12, no. 5, pp. 632-657, 2001.

[31] Y. Mishina, T. . Pollock, and J. . Porac, "Are more resources always better for growth? Resource stickiness in market and product expansion,” Strateg. Manag. J., vol. 25, pp. 1179-97, 2004.

[32] F.-T. Moussa, D. Marlin, and R. W.J., "Configurations of slack and their performance implications: an examination of high-tech IPOs," Manag. Decis., vol. 51, pp. 225-247, 2013.

[33] L. . Bourgeois and J. . Singh, "Organizational slack and political behavior among top management teams," Academy of Management Proceedings. pp. 43-47, 1983.

[34] O. . Moses, "Organizational slack and risk-taking behavior: tests of product pricing strategy," J. Organ. Chang. Manag., vol. 5, no. 3, pp. 38-54, 1992.

[35] R. Othman, A. M. Thani, and E. K. Ghani, "Determinants Of Islamic Social Reporting Among Top Shariah -Approved Companies In Bursa Malaysia," Res. J. Int. Stud., vol. 12, no. 12, pp. 4-20, 2009.

[36] L. . Preston and D. O'Bannon, "The Corporate Social-Financial Performance Relationship," Bus. Soc., vol. 36, pp. 419-429, 1997.

[37] S. Waddock and S. Graves, "The Corporate Social Performance-Financial 
performance Link,” Strateg. Manag. J., vol. 18, pp. 303-319, 1997.

[38] P. Arora and R. Dharwadkar, "Corporate governance and corporate social responsibility (CSR): The moderating roles of attainment discrepancy and organization slack," Corp. Gov. An Int. Rev., vol. 19, no. 2, pp. 136-152, 2011.

[39] A. Amran et al., "Social responsibility disclosure in Islamic banks: a comparative study of Indonesia and Malaysia," J. Financ. Report. Account., vol. 15, no. 7, pp. 99-115, 2016.

[40] F. Darus et al., "Social responsibility reporting of Islamic banks: Evidence from Indonesia," Int. J. Bus. Gov. Ethics, vol. 9, no. 4, pp. 356-380, 2014. 